\title{
Swimming and Diving in Grandpa's River: A Promise of Help with Respect to Water on Halalt Territory
}

\author{
Michael Graeme* \\ University of Victoria \\ mike_graeme@hotmail.com
}

\begin{abstract}
Drawing on media reports, court proceedings, and ethnographic literature, this paper explores contentions between the Halalt First Nation and the Municipality of North Cowichan regarding rights and access to the Chemainus Aquifer. Using a well project proposed by the municipality as a focus, I describe colonial power dynamics and argue that a decolonizing shift is needed in law and society to reconcile Indigenous and non-Indigenous ways of using and regulating resources on unceded Coast Salish territory.
\end{abstract}

Keywords: Halalt First Nation; Chemainus; Indigenous law; decolonization; Coast Salish

"If you take the protection - which is given to [the land] by spirituality - away from the land, there will be no guarantee that it will continue to produce and regenerate and be used for the next hundred, thousand, million years." Tsartlip Chief Tom Sampson (as cited in Kasten, 1987, p. 13)

1 he Halalt are an Island Hul'qumi'num community of the Coast Salish continuum, which is composed of "a large number of First Nations and Native American communities in and around the waters of the Strait of Georgia, Juan de Fuca Strait, Puget Sound and lower Fraser River" (Thom, 2005, p. 60). The land that the Halalt, or Xulelthw, bear the responsibility to protect includes Willy Island, both sides of the mouth of the Chemainus river, and up into the lower Chemainus Valley (Halalt First Nation v. British Columbia [Environment], 2011 BCSC 945). The lower Chemainus Valley was one of the first areas of colonial settlement of Hul'qumi'num territory by the British beginning in 1859, and disputes over access to the land have occurred ever since (Egan, 2012). Coast Salish rights to the land and its given resources have long had their foundations in the principles of Coast Salish kin networks (Thom, 2010). Boxberger (2007) recounts the colonial process

\footnotetext{
${ }^{*}$ I would like to thank Dr. Brian Thom for his compelling classes and supportive mentorship that helped me grasp an understanding of colonial dynamics on Coast Salish territory. Settler Note: I would like to acknowledge my position as a settler descendent living on Coast Salish territory. As is set out in the Truth and Reconciliation Commission and UVic's Indigenous Plan, it is a responsibility of settlers and settler institutions to engage in the work that moves us towards decolonization, and this is my motive for writing this paper. As I strive in this paper to inspire an understanding of Halalt law and stewardship, it is important to keep in mind that the Halalt are the experts and knowledge keepers of this information, not me. In this paper I have related information found in published resources, which by no means represent the totality of Halalt perspectives and ways of being: there exists an aquifer of private knowledge that is not shared publicly. Moreover, there exists a diversity of perspectives within any community. I hope that this paper is seen as an offering from a settler to the ongoing work towards decolonization in Canada.
} 
whereby the European notion of common law usurped that of Coast Salish common law, serving to diminish the influence of these kin-based governing systems and transfer their regulatory power into a new matrix of the dominant Western society's political economy 1 It is in such a context of unequal power dynamics that the Coast Salish, such as the Halalt First Nation, struggle to "achieve some degree of control over Aboriginal rights," which occurs "sometimes successfully, sometimes not successfully" (Boxberger, 2007, p. 57). In the case of the Halalt First Nation, achieving these rights is not an either-or distinction but rather occurs sometimes both successfully and not successfully.

Drawing on media reports, court proceedings, and ethnographic literature, this paper explores contentions between the Halalt First Nation and the Municipality of North Cowichan (MNC) regarding rights and access to the Chemainus Aquifer. Using a well project proposed by the municipality as a focus, I describe how Halalt ownership laws and ways of knowing collided with those of settler society and argue that a decolonizing shift is needed in law and society to reconcile Indigenous and non-Indigenous ways of using and regulating resources on unceded Coast Salish territory. I begin by describing the well project as detailed in the media, including the Halalt First Nation's concerns over the project's environmental soundness and the lack of consultation it received from the MNC. I then use ethnographic materials to discuss the history and law that tie the Halalt First Nation to the Chemainus River. This is followed by a contextual discussion of how Halalt and Western legal traditions conflict and how, despite landmark decisions made in the Western court system to honour Indigenous rights, power imbalances persist and consultation guidelines remain ambiguous. An analysis of media reports ensues, where I pick out themes of intercultural conflicts, such as the aforementioned power imbalances; the absence of and misunderstandings about Halalt connections to the Chemainus water in the media; differing views of consultation; and differing views of sustainable resource management. This leads to an exploration of attempted strides towards pursuing compatibility of Western and Halalt legal traditions, such as honouring Halalt oral tradition and ceremonial relationships in the courtroom. The theme of oral tradition and ceremonial relationships is again mobilized to illustrate water's preciousness for the Halalt. In culmination, I detail the result of the Halalt First Nation v. British Columbia (Environment) court case and discuss its implications.

\section{The Well Project}

The friction between Halalt First Nation and the MNC revolved around a well project proposed by the latter that would extract drinking water from the Chemainus Aquifer on the unceded territory of the former. In May, June, and July 2010, followed by an extension into November, representatives of the Halalt First Nation were present in Vancouver's courtroom opposing the establishment of the Chemainus well project (Siefken, 2010). Local media sources closely chronicled the conflict over the MNC's 5.7-million-dollar well project, which was proposed by the MNC in 2001 and then approved by the province in 2003 to provide the Town of Chemainus and surrounding area with potable drinking water extracted from this aquifer - especially in the months between September and June when the water quality of its surface reservoir tends to become turbid. This plan by the MNC to tap the aquifer lying beneath the Halalt reserve went forward with the Halalt First Nation left largely out of the discussion ("Halalt band claims," 2005; Kenneth, 2013; Siefken, 2010; Simpson, 2011; Thomson, 2009). Although an initial engineering report that the MNC released claimed the wells would not have any impact on the Chemainus River, the Halalt First Nation expressed concern early

\footnotetext{
${ }^{1}$ However, it is important to note that despite this diminishment, "the kin-based principles that underwrite indigenous communities' leadership, territories and property, political networking and the distribution of political power bases continue to profoundly influence choices in the ongoing formulation of indigenous self-determination" (Thom, 2010, p. 34).
} 
on that drawing from the aquifer would indeed affect the river. The Chemainus River is known to the Halalt First Nation as "Grandpa's River," and to which it has economic, social, ancestral and spiritual ties ("Halalt band claims," 2005; Halalt First Nation v. British Columbia [Environment], 2011 BCSC 945; "Halalt lay claim," 2005; "Halalt takes its water," 2007).

While the Halalt First Nation's concern about the aquifer affecting the Chemainus River was central, the duty to consult was another core consideration raised by the Halalt. Indeed, the case brought by the Halalt First Nation before the BC Supreme Court revolved not merely around the environmental soundness of the project. More precisely, it claimed that there had been inadequate consultation during all levels of the well project development process and that proper accommodation had not been discussed relating to the project's impact on their prima facie legal claim of Aboriginal Rights and Title ${ }^{2}$ (Gage, 2011; Halalt First Nation v. British Columbia [Environment], 2011; "Halalt seek to halt," 2009). This case is a microcosm for the general experience of First Nations in British Columbia when it comes to consultative processes. According to Booth and Skelton (2011), "in reviewing the large collection of procedural failings embodied within Canada's and British Columbia's consultative processes [...] one is struck by a disturbing larger picture" (p. 698). This larger picture is the flawed consultation process and the fact that despite recognition of this by the federal and provincial governments, little is being done to correct it (Booth \& Skelton, 2011). Media reports covering the well project dispute reveal the procedural failings posited by Booth and Skeleton. From the initial approval by the province in 2003, to later modifications of the well project's scope based on an assessment by the Environmental Assessment Office (EAO), the media reported that the Halalt First Nation claimed it never engaged in "deep consultation," while the MNC consistently maintained the opposite ("Halalt lay claim," 2005; Kenneth, 2013; Rusland, 2010; Simpson, 2010; Thomas, 2007). The example of the aquifer is an opportunity to examine the cultural differences, different interpretations of consultation, and colonial dynamics with which the Halalt First Nation continues to struggle.

\section{History and Law of the Halalt People}

The Halalt have a long relationship with the Chemainus River, which includes laws and obligations passed to them by their first ancestors. In ethnographic literature, Halalt, or Xulelthw, is described as meaning "marked houses" or "painted houses," and was the name of the village at the mouth of the Cowichan River before the village was moved to Willy Island (Rozen, 1985, p. 124). Beryl Cryer adds that these "painted markings" refer more specifically to a large image of a man paddling his canoe along the water, "chasing a whale" (as cited in Arnett, 2008, p. 290). This image was depicted on the big house in the Xulelthw village on Willy Island, where three families resided, so that visitors could see it as a beacon from far away (Arnett, 2008). In the early 20th century, the Halalt people living in this village on Willy Island were displaced to the Chemainus Reserve in Westholme on the banks of the Chemainus River (Rozen, 1985). Rozen (1985) and Thom (2005) also write that the first ancestor of the Halalt was St'uts'un, who fell from the sky 3 landing on Mount Prevost - at the mouth of the Chemainus River. Thom (2005) writes that St'uts'un had a painted house from which the Halalt community got its name. The design painted on St'uts'un's house "was powerful, private family knowledge and should never be revealed" (Thom, 2005, p. 92). Rozen (1985) writes that St'éts'en (i.e., St'uts'un) together with Siyóletse (i.e., Syalutsa), ancestor of the

\footnotetext{
${ }^{2}$ As part of the Hul'qumi'num Treaty Group, Halalt First Nation is in Stage 4 ("Agreement in Principle") of treaty negotiations encompassing freshwater resources, including groundwater, in the area of the project (Government of British Columbia, n.d.; Halalt First Nation v. British Columbia [Environment], 2011 BCSC 945).

${ }^{3}$ There are many variations on the spelling of this word; for example, Thom's spelling is "St'uts'un" while Morales' spelling is "Stuts'un" and Rozen's dated spelling is "St'ets'en."
} 
Cowichan people, were the originators of the first Xulelthw village at the Cowichan River mouth. These first ancestor stories reaffirm the deep ancestral connections between the Halalt, this land, and the water (Thom, 2005). They also create a framework for coming to understand and encounter the land (Thom, 2005) - a framework that is not discussed in the media sources I analyzed.

Ethnographic material specific to the Halalt is rare. This creates obstacles for a full understanding of Halalt law and obligation, land use and tenure, and the ways of knowing that are at the basis of the conflict between Halalt and settler governance of land and water. However, given the extensive consistencies among Coast Salish communities, it is possible to draw an accurate picture - especially around resource ownership and the importance of water among the Halalt - by integrating the available ethnographic work on the Coast Salish more generally (Thom, 2005). Multiple variations and levels of resource ownership exist among Coast Salish people. For instance, ownership rights might be held by a household, an extended kin network, a village group, or sometimes by a single individual via his or her descent (Deur \& Turner, 2005; Thom, 2009). Furthermore, the nature of ownership rights may range between a "general recognition of communal territory" to "authority over specific resource sites" (Deur \& Turner, 2005, p. 165). It is important to acknowledge that for Coast Salish groups "authority" does not equate with "exclusionary control" (Deur \& Turner, 2005, p. 165); rather, "normalized sharing has resulted in a dominant idiom of inclusion, influencing territorial relations with neighbours" (Thom, 2009, p. 186). Suttles (1960) further notes that the sharing of resources is not limited to sharing of the sites themselves but involves sharing the harvested resources as well, through reciprocal exchange and redistribution via potlatch, although this applies more to food and other items than water. To add yet another, exceedingly important, complexity to the relational nature of land and resource ownership, Thom (2009) notes that these relationships extend to include spirits and ancestors. Extended families come to connect to a specific area in the first place based on "historical and mythical privileges handed down by ancestors and learned by engaging in respectful spirit relations with the non-human persons in the land" (Thom 2005, p. 30). Thus, the words of Tsartlip Chief Tom Sampson from the epigraph of this paper, which explain that protection is given to the land by spirituality, ring more clearly.

The importance of first ancestors as the bridge to the living legal tradition of Coast Salish law is recurrent in the ethnographic literature. Morales (2018) writes of her personal relationship with the first ancestors:

Our snuw'ey'ulh or Hul'qumi'num laws, dictate that we have an inalienable connection to one-hundred percent of our traditional territory. They lay the foundation for how Hul'qumi'num people must continue our obligations in our relationship with the natural world, which is connected to us through the First Ancestors. (p. 155)

I look up towards Swuq'us; I see the face of my First Ancestor Stuts'un and remember the teachings he gave me.[...] I want [my community] to draw strength from the laws embedded in the lands [...] to see that we have a living legal tradition that operates within our communities and guides our daily decision-making processes. (p. 151)

As previously mentioned, the First Ancestor St'uts'un's house was the source of the Halalt's own name after he landed near the mouth of the Chemainus River. Later discussed in this paper, the Halalt do as Morales wishes and draw strength from the laws given by their first ancestors. There are certain methods for laws and teachings to be passed on to a Coast Salish recipient. Water itself plays a vital role in this transmission. Indeed, as Morales (2018) continues,

Laws are received from Hals (Creator) after a purification period or a retreat of months or years of daily bathing in cold water - in streams or lakes - and living with nature during this period. [...] 
The Arbutus Review • $2018 \bullet$ Vol. 9, No. $1 \bullet$ https://doi.org/10.18357/tar91201818388

When one receives a law from Hals (Creator), he would further bathe and fast to give thanks for the law or vision he has received. He must show his thanks for what he has received for it should be for the survival of his family, the community, and the resources. Once this law is in place, it is the responsibility of the parents and Elders to uphold this law and pass it onto their children and their children's children. (p. 164)

Water, then, is a sacred medium between the Coast Salish and the Creator through which law is transmitted. It is within this context that the Halalt have the obligation to uphold their responsibility to protect Grandpa's River, a river wherein perhaps the very laws being upheld were received through bathing visions. The fact that these relationships of law tied to kin, ceremony, the land, and spirit have been overlooked by settlers and the Western legal system demonstrates cultural misunderstandings that have led to the conflict over the right to use the Chemainus Aquifer.

\section{A Conflict of Legal Traditions}

Since the beginnings of European colonization of Coast Salish territory, there have been deep misunderstandings, delegitimization, and domination over Coast Salish use and ownership laws by European colonizers and settlers (Deur \& Turner, 2005). Despite this, "Indigenous legal traditions continue to exist and have an ongoing meaningful presence in many Indigenous people's lives and communities, including the Coast Salish people" (Morales, 2018, p. 14). However, Coast Salish laws and their source in kinship relations have not been seen by Canadian law as holding weight in the Constitution, but rather as "a constitutional whisper" (Morales, 2018, p. 146). It was in the landmark Delgamuukw decision that "the Gitxsan and Witsuwit'en reaffirmed the continuing vitality of their laws in the Supreme Court of Canada" (Deur \& Turner, 2005, p. 171). "This decision," writes Chadwick (2013), "was at the forefront of shifting and shaping [Canadian] law in this particular area as it was the first time that First Nations were recognized to have a legitimate interest in the encroachment of development on their traditional territory" (pp. 13-14). Furthermore, the Delgamuukw v. British Columbia case, along with Haida v. British Columbia and Taku River Tlingit First Nation v. British Columbia, which all drew on Section 35 of the Constitution Act, 1982 on Aboriginal and treaty rights, marked a turning point that gave priority to the "Duty to Consult" with First Nations before a development project is carried out on a traditional territory (Chadwick, 2013). Given any possibility of a development project affecting a community and its corresponding land, this "Duty to Consult" bestows government (federal and provincial) with the legal responsibility to ensure consultation is met and that a community is accommodated where appropriate (Chadwick, 2013). Consultation, which "should be 'meaningful', have the intention of reasonably addressing Aboriginal claims, and be carried out through a process that is timely, proactive, and transparent" (Chadwick, 2013, p. 5), has become a required component of the environmental assessment process significant to this paper.

Despite these landmark decisions, cultural misunderstandings and power imbalances persist. The "Duty to Consult" has different meanings for different parties, as is demonstrated in this paper. Moreover, the strategies used in consultation are not defined from a law and policy perspective, and in cases where a First Nation has not settled a land claim, such as the Halalt First Nation, that Nation does not have the authority to deny or approve a provincial land-use decision - in the eyes of the Canadian law (Chadwick, 2013). However, "the courts nevertheless stipulate that the consultation process must be engaged in, in good faith, by both First Nations and industry" (Chadwick, 2013, p. 5), although the implications of what "good faith" really means remain vague. To add to this, if a dispute has to be settled - such as the Halalt's perceived lack of meaningful consultation over the well project - the courtroom is the only authentic place to do it, from the perspective of Canadian law. In speaking of land claims, Wood (2010) puts it eloquently when he 
says that the state's claims to authority are validated by the mere fact that land claims issues are not heard anywhere other than within the courtroom. Enshrining the court system as the center for decisions about resource use and sharing goes against the time-honoured practice of centering these decisions in the relational ideology of the Coast Salish. In this colonially rooted dominant system, jurisdiction is given to the environmental assessment process to deem a project feasible. If a First Nation blows the whistle on inadequate consultation during this assessment process, the court system is appointed to settle the dispute. The favouring of Western law over Coast Salish law on the latter's unceded territory indicates that big structural renovations of these power dynamics are needed. As Willow (2013) writes, the current system forces First Nation communities to "fit their knowledge, beliefs, and ways of understanding the world into frameworks considered credible by a politically dominant settler society" (p. 881). As we will see in the Chemainus water case, after the Halalt fit their way of understanding the world into this framework, it was considered credible by the Supreme Court, but even this success did not last long.

\section{Media Reports on the Well Project}

The media releases chronicling the Chemainus Aquifer dispute describe the power struggle between the Halalt First Nation and the MNC. Many of these reports were quick to illuminate the power dynamics with which the Halalt First Nation is faced and the ways in which its participation in the project was being prevented. The Chemainus Courier quoted Halalt First Nation's project manager Jack Smith's description of the situation as being "a David and Goliath type struggle for us" ("Halalt takes its water," 2007, para. 8). The Cowichan News Leader Pictorial recounted declarations that the well project was being carried out in a manner that withheld jurisdiction from the Halalt First Nation over the way the aquifer was to be used even though their territory would likely be affected by it (Rusland, 2010). Georgia Dixon, a consultant for the Halalt First Nation interviewed in the Ladysmith-Chemainus, expressed her criticisms about the project's engineering report because it was, in her opinion, incomprehensible to wider audiences due to its esoteric nature ("Halalt lay claim," 2005). Moreover, she said, it lacked any input from Halalt elders ("Halalt lay claim," 2005), who are, in Chief Samuel Sam's words, "always there to slow down the process and make sure that we understand what we are doing" (Kasten, 1987, p. 13).

The theme of spiritual connection to the water is one that is only ever subtly revealed, and the details of its implications were absent from media reports. The Cowichan News Leader did quote Joe Fortin bringing attention to the important place water has in Halalt spiritual connections (Rusland, 2010), but this was a rare occasion in statements throughout the media and was not elaborated upon. The dimensions of Halalt spiritual connections to water become clearer in light of Coast Salish ethnographic material. As previously noted, for the Coast Salish, the land and the water are intimately wound up in kin relationships and relationships to the "spirit world" (Thom, 2009, p. 12). For the Halalt First Nation there is no sharing of resources without addressing not only the human beings, but also the ancestors and other powerful non-human beings that are in a longstanding connection with a place and with its water (Thom, 2009). The lack of consultation by the $\mathrm{MNC}$, the EAO, and the province as to if, and if yes, then how, the well project could proceed while honouring these connections appears to be at the heart of why the Halalt First Nation feels the well project proceeded unjustly.

Relationships of water and territory for the Halalt First Nation are inseparable from social, historical, and spiritual relationships (Thom, 2009), yet the Halalt are faced with a situation where the MNC seeking to use water connected to "Grandpa's River" has not recognized the importance of those relationships. Assessing North Cowichan past Mayor Tom Walker's view of the water, its critical place as a foundation for contemporary and ancestral relationships appears to be absent: 
The Arbutus Review • $2018 \bullet$ Vol. 9, No. $1 \bullet$ https://doi.org/10.18357/tar91201818388

Municipally, myself and my council, we're just looking to provide cost-effective, good, clean, safe drinking water to about 6,000 folks in the Chemainus area...I'm going to continue pushing as hard as I can for a solution to good, clean drinking water for Chemainus. The constitutional issues, that's basically between the province and the feds and Halalt. (Simpson, 2011)

By "constitutional issues," the MNC is referring to the responsibility of provincial and federal levels of government to reconcile ongoing historical colonial power relations. The responsibility of the MNC to settle this dispute indeed does not fall squarely on its shoulders. It is the legal duty of the provincial and federal governments to ensure the EA process is sound (Chadwick, 2013). Yet historical colonial power relations exist and are perpetuated not only from high levels of government but all the way down to individuals and family relationships (Hunt \& Holmes, 2015). Hunt and Holmes (2015) point to the "everydayness of decolonization" (p. 158), where acts of decolonization are "active, interconnected, critical, and everyday practices that take place within and across diverse spaces and times" (p. 156). That is, the responsibility of decolonization is not only a constitutional one. While the dominant society's legal duty is outside the realm of the MNC's capacity, the engagement of MNC members in attempts to transform colonial relationships and to demonstrate recognition of the Halalt's longstanding connection to the water is entirely possible. Not engaging with the Halalt on the aquifer issue thwarts progress in this respect.

\section{Differing Views of Consultation}

The MNC, albeit seeing the responsibility of participation in constitutional issues as lying in the hands of the federal and provincial governments, nonetheless still acknowledges the constitutional responsibility for consultation with the Halalt. However, differing views of what meaningful consultation entails are held by the MNC and the Halalt, and this lack of consensus has contributed to the conflict. While North Cowichan Mayor Jon Lefebure ${ }^{4}$ claims to have engaged in consultation with the Halalt First Nation since 2003 when the project was started, recurrent in declarations by the latter party is the criticism of North Cowichan's "lax First Nations consultation process" ("Halalt lay claim," 2005). Tylor George, a Halalt Band Council Member, agreed that there had been meetings for years, but that all have been fruitless (Rusland, 2010). To understand this perceived fruitlessness, it helps to note the previous Mayor's frequent statements in the media that his faith lies in the EAO's environmental assessment process to approve the project, indicating the view that the project's feasibility has its foundations first and foremost in non-Indigenous regulation and governance ("Halalt lay claim," 2005; "Halalt raises water," 2007; "Halalt seek to halt," 2009; Thomas, 2007).

In his publication in the Ladysmith-Chemainus Chronicle, Halalt Chief James Thomas described encounters by the Mayor and other municipal council members of North Cowichan with the Halalt First Nation as inevitably taking on an air of condescension towards the Halalt. His impression of the discussions was that the MNC was only informing the Halalt of its project plans without any bilateral dialogue, therefore withholding from the Halalt any opportunity for jurisdiction (Thomas, 2007). Chief Thomas said he had become aware of a Chemainus Town Hall meeting - to which he was not invited to attend - where the North Cowichan Mayor claimed discussions were "proceeding in order that North Cowichan can supply Halalt with water from the wells" (Thomas, 2007, para. 6, emphasis added). This appears to ignore the Halalt vision for self-determination and is reminiscent of Boxberger's (2007) notion of imposing mechanisms that marginalize Coast Salish from their resources. Chief Thomas retorted that the Halalt First Nation "certainly doesn't need to look to

${ }^{4}$ North Cowichan has had multiple mayors throughout the course of the proposed project. 
the municipality for its needs," and expressed his opinion that the MNC should address its water issues by improving its own system rather than "take the water that is precious to Halalt in so many ways" 15 (Thomas, 2007, para. 9). Chadwick's (2013) analysis of effective consultation in the EA process located the act of building trusting relationships at its foundation. In media reports, the Halalt First Nation claims it is being left out of the discussion and condescended to, demonstrating that this core tenet of consultation, the act of building trusting relationships, is being missed by the MNC.

\section{Science and Ceremony}

"Our perspectives, which unite our understanding of the land with our social and community activities, differ fundamentally from the compartmentalized views of knowledge that come out of Western science." Raymond Cormier, Secwepemc (as cited in McIlwraith \& Cormier, 2015, p. 39)

Many of the media reports are evidence that the MNC does not acknowledge the Halalt First Nation's aspiration for self-determination and their own laws. Furthermore, the MNC does not appear to understand the precious nature of water for the Halalt. In 2009, the EAO's assessment confirmed the Halalt First Nation's initial impression that there was indeed a physical connection between the Chemainus Aquifer and the Chemainus River. Even so, the MNC made no noticeable attempt in the media sources I analyzed to strengthen its grasp of cross-cultural understanding or to apologize for proceeding with the project before fully understanding the consequences. Recalling the words of Chief Samuel Sam, perhaps the input of Halalt elders would have been important to begin with "to slow down the process and make sure that we understand what we are doing" (as cited in Kasten, 1987, p. 13). Although the full dimensions of water's preciousness (i.e., relating to private spiritual knowledge) are not always openly shared by the Coast Salish due to apprehension of misuse (Boxberger, 2007), there is no evidence in the media reports that the MNC sought to understand or empathize with the Halalt's connections to the water. Such connections also include the concern of the Halalt First Nation that using the aquifer might affect the steelhead salmon runs in the Chemainus River (Gage, 2011), which are so key to Halalt lifeways, and serve as "a symbol of the relationship of the Coast Salish to natural, cultural, and intellectual resources" (Boxberger, 2007, p. 58). Instead, the emphasis is placed by MNC on maintaining ecological integrity through the lens of science as it is interpreted by the EAO, hence the Mayor's position that he "welcomes an environmental partnership with the [Halalt] band to guard the aquifer, but hopes they will accept the given scientific data" ("Halalt lay claim," 2005, para. 13). This approach replaces Coast Salish systems of regulating resources with those governed by the state (Boxberger, 2007).

Resources for the Coast Salish were, and are, believed to have been received, in Chief Tom Sampson's words, from "the Creator himself" and the principles that Coast Salish individuals possess and are "obligated to carry out" were also received by the Creator (as cited in Kasten, 1987, p. 7). According to the Hul'qumi'num Treaty Group, both the land and these associated principles for stewarding it were given to the original ancestors of the families who now hold them (Morales, 2018). When the EAO's 2009 assessment confirmed the connection of the river and aquifer, it consequently requested that the project be substantially scaled down. Instead of the three wells initially proposed, the request called for a limit of two wells with the condition that only one be operational at any given time. Pumping, moreover, could only begin in mid-October as opposed to September. However, this scientific development, as well as the corresponding recommendation for

\footnotetext{
${ }^{5}$ Here, Chief Thomas is pointing directly to the colonial process of turning to land or resources of another instead of taking responsibilities to care for one's own. Yet it is a paradoxical example, as the territory outside the Halalt reserve is, too, unceded.
} 
modification, were both made without the Halalt First Nation's control or access to the discussion, when it is the Halalt who hold the regulatory principles, passed down by the ancestors, to the water being investigated (Gage, 2011; Kasten, 1987; Rusland, 2011). Of these regulatory principles, two are underlined by Chief Sampson. The first, spirituality, refers to "a clear understanding of ourselves and the Creator, which enables us to communicate with Him through spiritual means" (Kasten, 1987, p. 7). The second is conservation, which is based on using resources respectfully as defined by the Creator. Therefore, Chief Sampson emphasizes that knowing and understanding the "ceremonies that go with the use of the resources" is above all a necessity (Kasten, 1987, p .8). Receiving no attempt to address the ceremonies or the spiritual responsibilities associated with the water of the Chemainus River, the Halalt First Nation felt a lack of "deep consultation," and instead felt that its water, "precious to the Halalt in so many ways," was being expropriated (Thomas, 2007, para. 6).

\section{Water's Preciousness in the Oral Tradition}

Although ethnographic material focusing specifically on the Halalt First Nation is scarce, historical and ethnographic material about other Nations convey the preciousness and sacred quality of water present throughout Coast Salish territory, and how in other instances, too, this water has been subject to external plans imposed in a colonial manner. Duff (1969), for instance, relates the story of q'ama'sarj, after which Camossung Gorge was named, in which a girl, helped by the Transformer, decides the composition of the ecology of the area and is granted the responsibility of controlling it. Eternalized in stone at the bottom of the river, q'ama'sarj, and the history she represents, become literally encapsulated in the water, and the power with which the water is imbued has the potential to be accessed by those diving, or bathing, within it (Duff, 1969, p. 36). When James Douglas mapped out the Gorge, he could not see this power or the story beneath the surface, and his map he wrote the measurement 47$]^{6}$ while envisioning the machinery that would be traveling through the Gorge to develop what was to be Fort Victoria (Duff, 1969).

For the Klallam on the south side of the colonial disseverance of Coast Salish territory known as the 49th parallel, the Elwha River is similarly associated with story and spiritual power. In contrast to the issues faced by the Halalt First Nation, instead of extracting water via two pumps, two industrial dams were built on the Elwha to extract hydroelectric energy without consultation or associated ceremonies. Although recently removed due to being outdated, unneeded, and in conflict with modern environmental laws, the invasiveness of these dams for the Klallam was in many ways unfathomable. Indeed, The Klallam believe that it was from the mud at the bottom of the Elwha River, in between where the two dams were located, that the Creator scooped the lump of dirt from which the first humans were formed (Boyd \& Boyd, 2012). Moreover, these dams prevented the Elwha River from receiving the steelhead runs that have sustained the Klallam for generations and, similar to the case of the Halalt First Nation, have been at "the foundation for Klallam governance, economy, and social life" (Boyd \& Boyd, 2012, p. 424). Now, over a hundred years after Elwa River dam construction began, the disassemblement of the two dams, namely the Glines Canyon Dam, marked the largest dam removal in U.S. history, and the Elwa River is now being restored with participation from the Klallam (Lower Elwa Klallam Tribe, n.d.).

\section{Opening the Umbrella of Science}

Boyd and Boyd (2012) note that the ancestral right of stewarding the environment and the principles that go along with resource control and access have been identified through oral tradition,

\footnotetext{
${ }^{6}$ The measurement type is not specified in Duff's article: "James Douglas saw it with a different eye. On his 1842 map he did not write its name but the number 47 , which was his estimate of its width" (p. 36).
} 
long before the nation-state's legal scripts allowed industry and governments to begin executing their own resource management plans. In this light, it is significant that another release by Cowichan News Leader Pictorial reported a project was being set out to accomplish a literary recording of the Halalt First Nation's oral history in order to provide an accessible reference of the Halalt's deep relationship to the Chemainus water ("Halalt historic connection," 2006). The publication presented Jack Smith's perception of this project as "part of the science in relation to the ongoing management of the aquifer" ("Halalt historic connection," 2006, para. 7), demonstrating a push for the umbrella of science to be opened to include Coast Salish intimate, contemporary, and historical observations and connections with their land and resources.

To fully understand the significance of honouring Halalt oral history of the Chemainus River and its surroundings is to realize that these oral histories bring into the center of the discussion the "historical and mythical privileges handed down from the ancestors" (Thom, 2009, p. 12) to the Coast Salish. Recalling the 1997 Delgamuukw v. British Columbia case that established oral history as having comparative importance to written history and as being able to be used in court (Boxberger, 2007), the Halalt case then provides ripe conditions for a shift in Western consciousness as to the "ancestral quality" of the water. This shift would encompass a view that the ultimate right to the water does not primarily involve accomplishing the Western science portion of an environmental assessment, but rather is first about recognizing the order established through age-old social and hereditary relationships and their spiritual sources (Kasten, 1987; Thom, 2009).

However, as Carlson (2007) posits, there are shortcomings to the ostensible success of the Delgamuukw v. British Columbia case in terms of honouring oral history in the courtroom.

Much of the cause for disjuncture lies in the assumption found within the $1997 \mathrm{Del}$ gamuukw decision that native oral histories work in fundamentally the same way as Western history, and that these bodies of indigenous knowledge will therefore necessarily supplement and enrich an existing historiography and jurisprudence derived from what are largely archival-based understandings of past happenings. (p. 47)

Carlson shows that oral histories are seen in the courtroom in a relative light to documentary sources. Whether written or oral historical information will be seen as subordinate, and which as legitimate, if the two run counter to each other, is a question settled in the courtroom. This motions to the fact that the Western legal system remains the entity in power with the final say, rather than Coast Salish systems of validation.

\section{"Sometimes Successfully, Sometimes Not Successfully"}

In culmination of the Halalt First Nation v. British Columbia (Environment) court case regarding lack of consultation with the Halalt First Nation, the final judgment released in July of 2011 suggested that there was a shift towards decolonization in the Vancouver courtroom in 2010. Due to the nature of the case, it was not ruled whether or not the Halalt actually hold Aboriginal Title to the aquifer in question (it remains prima facie as the treaty process proceeds). Moreover, there was no explicit mention in the "Reasons for Judgment" of the hereditary kinship mechanisms in place that should be honoured as the determining factors for access to the aquifer. There was a brief mention of Halalt elders, as the document stated, "Halalt's elders believe there is an intricate and important interaction between the River and the Aquifer" (Halalt First Nation v. British Columbia [Environment], 2011 BCSC 945, para. 16). Yet, there was no mention of the first ancestors who presented the Halalt with their laws and obligations to the water. The judge did, however, allude to the ancestral quality of the Chemainus River by noting the ceremonial use of the river via bathing. The judge concluded on the evidence she received that "the River is, and has been traditionally, 
integral to the lives of Halalt because of its fish and fish habitat, plants and bathing holes. It sustains the animals the Halalt people hunt and the plants they gather" (Halalt First Nation v. British Columbia [Environment], 2011, para. 560). The judge's allusion to ritual bathing is significant, as bathing is one of the most vital ongoing aspects of Coast Salish spiritual life (Suttles, 1981; Thom, 2005).

For a decision in the Western legal system to be established, in part, on ceremonial practice offers legitimacy to Halalt law and spiritual obligation to the land. As previously examined, bathing is integral to interpreting Coast Salish law. Bathing, or kw'aythut, is a spiritual cleansing that, through a process of "appropriate engagement with the land," enables one to "become strong" (Thom, 2005, p.152, p. 154). Recalling Chief Tom Sampson's first principle of spirituality, performing kw'aythut is to participate in the relationship with the spirits and ancestors who imbue the landscape (Kasten, 1987; Thom, 2005). Thom (2005, p. 7) argues that drawing on this experience in the courtroom is in fact drawing on the power that is created out of this relationship, legitimizing in this case Halalt engagement with the Chemainus River. By acknowledging the well project's potential consequence on bathing holes, the judge was, if indirectly, honouring the longstanding Halalt engagement with the land and the spirits inhabiting it, and thereby the ceremony and the ancestral relationships that determine access and control of the river's water. The judge also concluded that the depth of consultation during the environmental assessment process was insufficient and the Environmental Assessment Certificate would be shelved, prohibiting any pumping from the wells:

Halalt was owed deep consultation as a result of the prima facie strength of its claims respecting both Aboriginal rights and title. Even if the EAO intended to engage in deep consultation with Halalt, it did not do so in fact. The consultation process was inadequate 7 (Halalt First Nation v. British Columbia [Environment], 2011 BCSC 945, para. 710$)$

This latter judgment is similarly significant, as it demonstrates the living legacy of the Delgamuukw, Haida, and Taku River Tlingit First Nation v. British Columbia cases, which set the legal precedent for development projects requiring consultation with affected First Nations.

Although the courtroom became a temporary means for the Halalt First Nation to undermine the continuation of its hegemonic marginalization, the verdict was appealed in the BC Court of Appeal in 2012. In this latter case, it was held that consultation had in fact been legally adequate, and the Halalt First Nation's attempt to overturn the ruling was this time "not successful" (Boxberger, 2007, p. 57; Hargraves, 2013). In the EAO's (2018) report, it writes,

The BC Court of Appeal (BCCA) set aside the BCSC [BC Supreme Court] order and found that the Environmental Assessment Office (EAO) had met the duty to consult, and that consultation was at the deep end. (p. 1)

The Project as proposed during the EA originally involved year-round pumping, and the record indicated multiple reports, meetings, and communications had occurred regarding the effects of year-round pumping. The Project was subsequently modified to provide for winter pumping only so as to avoid any potential adverse effects of summer pumping. This modification was an accommodation of the Halalt's Aboriginal Interests. (pp. 1-3)

\footnotetext{
${ }^{7}$ The judge's evidence as to the strength of Halalt prima facie claims to Aboriginal rights and title was based in a 55-page commentary given to the EAO by the Halalt, delineating "the history of Halalt's presence in the Project area and its assertion of Aboriginal title and rights," as well as on a map drawn by Franz Boas and later re-illustrated by Brian Thom that demonstrated Halalt territory as existing exclusively on "both sides of the mouth of the Chemainus River and inland for an unknown distance" (Halalt First Nation v. British Columbia [Environment], 2011 BCSC 945, paras. 152,466$)$.
} 
The shortcomings of both consultative and Western legal processes here are highlighted by the fact that there is no reference to Halalt law, spiritual obligation, or relationships that govern resource use in the discourse, which is at the very heart of why the Halalt First Nation strongly stated, from the beginning, that consultation was indeed not "at the deep end," as the EAO report claims above. The Court of Appeal assumed both adequate consultation and appropriate accommodation was given, and this legal judgement is the one that settler society sees as ultimately holding weight. Moreover, following the court case, the MNC submitted an amendment application in request of pumping in the summer months, which disregards the core accomodation given to the Halalt First Nation prohibiting year-round pumping (Environmental Assessment Office, 2018). In its own report, the EAO notes that the Halalt "stated their view that prohibiting summer pumping in the original certificate was an accommodation to their Aboriginal Interests and therefore the EAO should not be considering an amendment that would allow the operation of the Chemainus Wells during the summer" (Environmental Assessment Office, 2018, p. 12). Yet, the report goes on to consider the amendment, proposing various conditions to appease the Halalt's concern. In crafting these conditions, the EAO does seek input from the Halalt, but the EAO appears to overlay its beliefs of what the Halalt want over the Halalt's input. For example, in speaking of one of the conditions of this amendment, the EAO's own report states, "The EAO believes that the objective of this revised condition adequately addresses Halalt's concern with respect to requesting only a time-limited approval [to pumping in summer months], although the EAO acknowledges that Halalt does not share this view" (Environmental Assessment Office, 2018, p. 14). The basic nature of the relationships of power appears to remain the same: The Halalt voice remains secondary and rather than being honoured by the MNC and EAO, it is treated as an obstacle that can be bypassed.

The conclusion of the Halalt First Nation v. British Columbia (Environment) case did not result in the Halalt First Nation and the MNC seeing eye-to-eye, nor did either party concede its position. In the Cowichan Valley Citizen, Chief Thomas was quoted as saying that, despite the loss, the Halalt First Nation's position had not changed since the beginning of the project and their struggles would continue: "We take our role as stewards of the river very seriously" (Simpson, 2013). What is more uncertain is whether or not the MNC's conceptual position will be altered. Statements in the media seem to indicate otherwise. For example, in the Cowichan Valley Citizen, North Cowichan Municipal CAO Dave Devana says, "Hopefully we don't make any of the mistakes we made last time and keep them well informed this time. Hopefully this thing will go smoother than it went last time. But in the end it's up to the minister and the EAO to decide" (Bainas, 2014, emphasis added). Devana thus continued to disregard Halalt First Nation's self-determination and its longstanding regulatory relationship of the water.

\section{Conclusion}

The Chemainus well project is a good vantage point for seeing the ongoing colonial dynamics faced by the Coast Salish today, yet this vantage point may be obscured by reading media reports and court decisions alone. The deep spiritual and ancestral connections between the Halalt First Nation and the water were not elaborately discussed in either the media or the court decisions. The majority of the emphasis in the media and the courtroom remained on the surface contention over the aquifer. By employing ethnographic resources, this paper attempted to shed light on and develop a cross-cultural understanding of the deep connections the Halalt First Nation has to the Chemainus water. When the Halalt's initial victory in the courtroom was overturned by the BC Court of Appeal in 2012, it was demonstrated that even if a success is achieved via the legal construct of the dominant society, its permanence is not guaranteed. What appears to be more dependable is the continued legitimization of land and resource regulation by non-Indigenous governments and 
settlers (Boxberger, 2007). This does not, however, mean that the work achieved by the Halalt First Nation in the courtroom was fruitless. Thom (2005) points out that the Coast Salish struggle in the courtroom around land claims, which is carried out in responsibility to the land and the ancestors, is itself a form of spiritual engagement and being-in-the-world that emulates other practices of the Coast Salish world. Barnett (1938) describes a Coast Salish bathing rite of passage discussed earlier as "swimming and diving, often to the point of exhaustion or unconsciousness, in which state [the initiate] received a vision, a song, a spirit cry, and promise of help according to the nature of his wishes" (p. 135). It is questionable whether the swimming and diving of the Halalt in the realm of the dominant society's legal system will also offer such promise of help, but if there is any vision that I have received from swimming and diving in the process of writing this paper, it would be how imperative and compelling it is for the colonial legal system to undergo a decolonizing shift in how resources and disputes surrounding them are dealt with in order to reflect the governing systems of all the parties involved. In this venture, those ancient systems of law and resource use belonging to the first inhabitants of this land should be put at the forefront. Moreover, as Booth and Skelton (2011) noted, this is one case of many where a consultation failure occurred and this trend calls for a renovation of the consultative process. The impetus for the shift in both of these avenues seems to be based in relationship building and bridging the gap between different conceptions of resource regulation.

There are countless opportunities to alter relationships of oppression outside of the legal system. This begins in contemporary life and stems from respectful attempts to understand and empathize with the cross-cultural differences and interpretations beneath the surface of disputes like that involving Grandpa's River. The MNC's comments reflect the colonial logic that Western legal institutions are above Indigenous ones. The exaltation of science above Indigenous ways of knowing and of the courtroom over Indigenous legal traditions are two examples. Carlson (2007) writes, "Whereas the forces of globalism have long compelled indigenous people to try and see the world as the colonizers do, representatives of colonial society have only recently begun to recognize the value of inverting this paradigm, of appreciating the value of indigenous knowledge and ways of knowing" (p. 47). It is paramount that members of settler society make a conscious effort to appreciate the values of those on whose land they now reside, use, and extract resources. Attempts to understand not only Halalt conceptions of the land and water, but the laws that go to the source of those conceptions, while doing so on Indigenous terms, can aid in a re-envisioning of the land and water and how to navigate such conflicts as that which arose between the Halalt First Nation and the MNC. For these attempts to be successful, settler society and settler institutions must refrain from turning only to their own systems of regulation, and learn to listen, more deeply, to the First Nations whose time-honoured ties to the land and water have provided for their protection thus far. From this space, where all stories and relationships to the water can be fathomed, where true and meaningful dialogue can be undertaken, such rivers as Grandpa's River can "continue to produce and regenerate and be used for the next hundred, thousand, million years" (Sampson as cited in Kasten, 1987, p. 13). 
The Arbutus Review • $2018 \bullet$ Vol. 9, No. $1 \bullet$ https://doi.org/10.18357/tar91201818388

\section{References}

Arnett, C. (2008). Two houses half-buried in sand: Oral traditions of the Hul'qumi'num Coast Salish of Kuper Island and Vancouver Island. Vancouver, Canada: Talonbooks.

Bainas, L. (2014, June 20). District aims for year-round use of Chemainus wells. Cowichan Valley Citizen. Retrieved from http://search.proquest.com.ezproxy.library.uvic.ca/docview/1539091088?accountid $=14846$

Barnet, H. G. (1938). The Coast Salish of Canada. American Anthropologist, 40(1), 118-141. Retrieved from http://www.jstor.org/stable/661796

Booth, A. L., \& Skelton, N. W. (2011). "You spoil everything!" Indigenous peoples and the consequences of industrial development in British Columbia. Environment, Development and Sustainability 13(4), 685-702. Retrieved from https://doi-org.ezproxy.library.uvic.ca/10.1007/s10668-011-9284-x

Boxberger, D. L. (2007). The not so common. In B. G. Miller (Ed.), Be of good mind: Essays on the Coast Salish (pp. 55-81). Vancouver, Canada: UBC Press.

Boyd, C. E., \& Boyd, J. B. (2012). Cultural survival, tribal sovereignty and river restoration on the central northwest coast, North America. In B. R. Johnston (chief), L. Hiwasaki, I. Klaver, A. R. Castillo, V. Strang, M. Barber, \& D. Niles (Eds), Water, cultural diversity $\& 3$ global environmental change: Emerging trends, sustainable futures? (pp. 418-433). Jakarta, Jl: UNESCO-IHP and Dordrecht, NL: Springer. Retrieved from https://doiorg.ezproxy.library.uvic.ca/10.1007/978-94-007-1774-9_27

Carlson, K. T. (2007). Reflections on Indigenous history and memory: Reconstructing and reconsidering contact. In J. S. Lutz (Ed.), Myth \& memory: Stories of Indigenous-European contact (pp. 46-68). Vancouver, Canada: UBC Press.

Chadwick, M. (2013). The duty to consult First Nations within the environmental assessment process: A resource industry perspective (Master's thesis). Retrieved from https://dspace.library.uvic.ca/bitstream/handle/1828/5140/Chadwick_Megan_MA_2013.pdf?sequence=1\&isAllowed=y

Deur, D., \& N. J. Turner. (2011). Keeping it living: Traditions of plant use and cultivation on the northwest coast of North America. Seattle, WA: University of Washington Press.

Duff, W. (1969). The Fort Victoria treaties. BC Studies, 3, 3-57.

Egan, B. (2012). Sharing the colonial burden: Treaty-making and reconciliation in Hul'qumi'num territory. The Canadian Geographer 56(4), 398-414. Retrieved from https://doi.org/10.1111/j.1541-0064.2012.00414.x

Environmental Assessment Office. (2018). EAO's assessment of an application for certificate amendment. Chemainus Wells Water Supply Project EA Certificate \#W09-01. Municipality of North Cowichan. Retrieved from https://projects.eao.gov.bc.ca/api/document/5acf9f4ad666d000248$57124 /$ fetch

Gage, A. (2011). Halalt Nation's win protects Chemainus River. West Coast Environmental Law [website]. Retrieved from https://www.wcel.org/blog/halalt-nations-win-protects-chemainusriver

Government of British Columbia. (n.d.). Halalt First Nation. Retrieved from https://www2.gov.bc.ca/gov/content/environment/natural-resource-stewardship/consulting-with-first-nations/first-nations-negotiations/first-nations-a-z-listing/halalt-first-nation

Halalt band claims town of Chemainus' new water source. (2005, January 19). Cowichan News Leader. Retrieved from http://search.proquest.com.ezproxy.library.uvic.ca/docview/374494809?accourtid=14846

Halalt First Nation v. British Columbia (Environment), 2011 BCSC 943. Retrieved from: http://www.courts.gov.bc.ca/jdb-txt/SC/11/09/2011BCSC0945.htm 
The Arbutus Review • $2018 \bullet$ Vol. 9, No. $1 \bullet$ https://doi.org/10.18357/tar91201818388

Halalt historic connection to the river being recorded. (2006, September 30). Cowichan News Leader. Retrieved from http://search.proquest.com.ezproxy.library.uvic.ca/docview/374544931?accountid $=14846$

Halalt lay claim to Chemainus River aquifer. (2005, January 18). The Ladysmith-Chemainus Chronicle. Retrieved from http://search.proquest.com.ezproxy.library.uvic.ca/docview/374410382?ac. countid=14846

Halalt raises water concerns. (2007, September 1). Cowichan News Leader. Retrieved from http://search.proquest.com.ezproxy.library.uvic.ca/docview/374674751?accountid=14846

Halalt seek to halt well project. (2009, September 7). The Ladysmith-Chemainus Chronicle. http://search.proquest.com.ezproxy.library.uvic.ca/docview/374310029?accountid=14846

Halalt takes its water message to University of Victoria group. (2007, November). Chemainus Courier. Retrieved from http://www.polisproject.org/PDFs/couriernov07_p9.pdf

Hargraves, M. (2013, March). Court of Appeal overturns trial victory for Halalt First Nation. Stewart McDannold Stuart [website]. Retrieved from http://www.sms.bc.ca/2013/03/courtof-appeal-overturns-trial-victory-for-halalt-first-nations

Hunt, S., \& Holmes, C. (2015). Everyday decolonization: Living a decolonizing queer politics. Journal of Lesbian Studies, 19(2), 154-172. Retrieved from https://doi.org/10.1080/10894160.2015.970. 975

Kasten, E. (1987). The return of the elders: Contemporary trends in Indian self-government on the northwest coast. Sociologus, 37(1), 1-19.

Kenneth, T. J. (2013, July 11). Halalt First Nation v. British Columbia (Ministry of Environment) File No. 35179, SCC (Lebel, Karakatsans, and Wager JJ). Border Ladner Gervas. Retrieved from http://www.blg.com/en/newsandpublications/publication_3435

Lower Elwa Klallam Tribe. (n.d.). River Restoration [website]. Retrieved from https://www.elwha.org/departments/river-restoration/

McIlwraith, T., \& Cormier, R. (2015/16). Making place for space: Land use and occupancy studies, counter-mapping, and the supreme court of Canada's Tsilhqot'in decision. BC Studies 188, 35-53. Retrieved from http://ojs.library.ubc.ca/index.php/bcstudies/article/view/186217

Morales, S. (2018). Locating oneself in one's research: Learning and engaging with law in the Coast Salish world. Canadian Journal of Women and the Law 30(1), 144-167. Retrieved from https://muse.jhu.edu/article/690053

Rozen, D. L. (1985). Place-names of the Island Halkomelem Indian people (Doctoral dissertation). Retrieved from https://open.library.ubc.ca/cIRcle/collections/831/items/1.0096521

Rusland, P. (2010, March 6). Halalt blockade about well-water rights gains citizen support during rally. Cowichan News Leader Pictorial. Retrieved from http://search.proquest.com.ezproxy.library.uvic.ca/docview/747249187?accountid $=14846$

Rusland, P. (2011, July 13). UPDATED: Judge turns off Chemainus wells tap indefinitely. Cowichan News Leader Pictorial. Retrieved from https://search-proquest-com.ezproxy.library.uvic.ca/do. cview/876276368/696F67E02B50468BPQ/1?accountid=14846

Siefken, K. (2010, July 27). Halalt water case pushed back until November. Cowichan News Leader Pictorial. Retrieved from http://search.proquest.com.ezproxy.library.uvic.ca/docview/732983716 ?accountid $=14846$

Simpson, S. (2010, March 3). Halalt blockade local roadway. Cowichan Valley Citizen. Retrieved from http://search.proquest.com.ezproxy.library.uvic.ca/docview/358025332?accountid=14846

Simpson, S. (2011, October 14). Halalt rights outweigh boil orders: Judge; North Cowichan cannot use wells. Cowichan Valley Citizen. Retrieved from http://search.proquest.com.ezproxy.library.uvic.ca/docview/898490000?accountid=14846 
Suttles, W. (1960). Affinal ties, subsistence, and prestige among the Coast Salish. American Anthropologist 62(2), 296-305. Retrieved from http://www.jstor.org/stable/667902

Suttles, W. (1981). The Coast Salish need for wilderness. In Onat, A.R. \& J.L. Hollenbeck (Eds.), Inventory of Native American religious use, practices, localities and resources: Study area on the Mt. Baker-Snoqualmie National Forest Washington State (pp. 698-716). Seattle, WA: Institute of Cooperative Research, Inc.

Thom, B. (2005). Coast Salish senses of place: Dwelling, meaning, power, property and territory in the Coast Salish world (Doctoral dissertation). Retrieved from https://www.researchgate.net/publication/41615918_Coast_Salish_senses_of_place_dwelling_meaning_power_property_ and_territory_in_the_Coast_Salish_world

Thom, B. (2009). The paradox of boundaries in Coast Salish Territories. Cultural Geographies, 16(2), 179-205.

Thom, B. (2010). The anathema of aggregation: Toward 21st-century self-government in the Coast Salish world. Canadian Anthropology Society, 52(1), 33-48. Retrieved from http://www.jstor.org.ezproxy.library.uvic

Thomas, Chief James R. (2007, May 22). Halalt disturbed by poor consultation over North Cowichan's aquifer plans. The Ladysmith-Chemainus Chronicle. Retrieved from http://search.proquest.com.ezproxy.library.uvic.ca/docview/374440750?accountid=14846

Thomson, S. (2009, March). Well plan draws fire. Ladysmith Chronicle. Retrieved from http://go.galegroup.com/ps/i.do?id=GALE\%7CA195800843\&v=2.1\&u=uvictoria\&it $=\mathrm{r} \& \mathrm{p}=\mathrm{CPI} \& \mathrm{sw}=\mathrm{w} \& \mathrm{a}$ sid $=2 \mathrm{f} 749 \mathrm{afe} 8605178 \mathrm{~d} 2 \mathrm{e} 1755 \mathrm{e} 3 \mathrm{~b} 042 \mathrm{dd} 48$

Willow, A. (2013). Doing sovereignty in native North America: Anishinaabe counter-mapping and the struggle for land-based self-determination. Human Ecology 41, 871-884. Retrieved from https://www.jstor.org/stable/24015746?seq=1\#page_scan_tab_contents

Wood, D. (2010). Rethinking the power of maps. New York, NY: The Guilford Press. 